\title{
A ,VIDÉKI” SZUBURBANIZÁCIÓ MAGYARORSZÁGON, PÉCS PÉLDÁJÁN
}

\author{
(Suburbanization in Hungary - A Case Study of Pécs)
}

\section{BAJMÓCY PÉTER}

\section{A szuburbanizáció fogalma}

A szuburbanizációt - mint folyamatot - egy megközelítés szerint a globális urbanizációhoz kapcsolva érdemes vizsgálni (Enyedi 1988). Ebben a vonatkozásban a szuburbanizáció egyaránt jelent koncentrációs és dekoncentrációs folyamatot is. Koncentráció az egész ország vonatkozásában, hiszen a rurális térségek rovására a nagyvárosi térségek tovább növekednek, a vidékrỏl, elsösorban a hanyatló falusi térségekböl való elvándorlás tovább tart. Dekoncentráció azonban magának a nagyvárosnak, a nagyvárosi zónának a vonatkozásában, hiszen a népességnövekedés súlypontja a nagyvárosról, mint a zóna magterületéről a városközeli falvakba, a gyürübe tevődik át. Dekoncentráció azonban abban a vonatkozásban is, hogy tényleges mozgások indukálódnak a nagyvárosból az agglomerációba, tényleges kiköltözések történnek a nagyvárosból a környékbeli falvakba (Tímár 1995).

\section{A magyarországi (szub)urbanizáció rövid története}

A magyarországi urbanizációt, így a szuburbanizációs szakaszt is a megkésettség jellemzi a nyugat-európai folyamatokhoz képest (Enyedi 1988). Az semmiképpen sem vitatható, hogy jelenleg Magyarországon a legkomolyabb szuburbanizációs folyamatok a fóváros környékén zajlanak, s ehhez képest bármelyik nagyváros körüli népességvándorlási tendencia jelentéktelennek tưnhet.

A nyugati szuburbiák gazdag elövárosok. Magyarországon azonban a szocialista időszak alatt vagy hiányoztak a szuburbiák, vagy a vidékról a városba migráló, ám magába a városba beköltözni nem tudó (vagy nem akaró) népesség hozott létre elóvárosokat. Így néhány Budapest környéki Budai-hegység-beli településtól eltekintve szegény szuburbiák jöttek létre. A rurális elemek sokkal erősebben jelentek meg az agglomerációkhoz tartozó telepủléseken, mint a hasonló nyugat-európai nagyvárosok esetében. A házak építési stílusa, jegyei a rurális térségek falusi házaihoz hasonlítanak, sokan foglalkoztak a ház körüli kiskertekben növények termesztésével, vagy állattartással. A falvakból a nagyvárosok felé migráló lakosság egy része saját szándéka szerint is a nagyváros körüli falvakat preferálta, hiszen így a váltás sokkal kisebb volt, a falusi házat egy másik falusi házra lehetett felcserélni, nem egy nagyvárosi bérházra. 
Bajmócy Péter : A „vidéki" szuburbanizáció Magyarországon, Pécs példáján.

Tér és Társadalom 14. évf. 2000/2-3. 323-330. p.

A vidéki nagyvárosok esetében a második világháború után, de leginkább a hatvanas évektől a gyors urbanizáció volt a jellemző. A városi népesség növekedése szinte kizárólag (egyes idegenforgalmi jellegü városoktól eltekintve) az iparhoz volt köthető. Ahogy erősödött az ipari decentralizáció, úgy gyorsult a vidéki közép- és nagyvárosok, elsősorban a megyeszékhelyek növekedése. A megyeszékhelyeken meglévő nagyvárosi lakáshiány és a falusi családi ház vonzóereje miatt egyes városközeli falvak népessége is növekedésnek indult (vagy folyamatosan tovább növekedett). A növekedés bázisát azonban itt is a távoli falvakból való beköltözés jelentette, és a rurális jegyek is hasonlóak, mint Budapest környékén. A különbség a jelenség mértékében van.

Az 1980-as évek a vidéki közép- és nagyvárosok esetében változást hoztak. A gazdaság növekedési üteme visszaesett, lecsökkent az állami lakásépítések üteme is. Az épülő új lakások egyre nagyobb hányada származott magánerős építkezésekböl. A lakásépítések összvolumene is visszaesett. Az urbanizáció üteme lassult, az ingázás állandóvá válása miatt egyre kevesebben költöztek a városokba. A vidéki nagyvárosok, elsősorban a megyeszékhelyek nagy részének a népességnövekedése azonban még folyamatos, bár kisebb mértékủ volt, mint az elöző dekádban. 1981től természetes fogyás váltotta fel az addigi természetes szaporodást.

\section{A kiteljesedö szuburbanizáció}

A nyolcvanas évek második felétől megindult a szuburbanizáció Magyarország nagyobb vidéki városai körül, méghozzá mindkét értelemben. Egyrészt a központi városok helyett a népességnövekedés súlypontja a gyürübe, a városokat övezö falvakba tevödött át. Kivételt jelent néhány erősen ipari jellegủ nagyvárosunk (Miskolc, Tatabánya), ahonnan a népesség elvándorlása már a nyolcvanas években megindult, és az elvándorlás részben a közeli falvakba, részben viszont az ország távoli vidékei felé irányult. İgy a csökkenő népességủ nagyváros melletti növekvő falvak dekoncentrációt jelentenek, melynek okai egyes iparágak strukturális válságában keresendők. Másrészt tényleges kiköltözési folyamtok indultak meg a nagyvárosokból a környező falvakba. A szuburbanizáció azonban több szempontból is speciális időszakban indult meg Magyarország területén. Egyrészt a szuburbanizáció megindulása a természetes fogyás időszakára esik, és ez azért lényeges, mert elvileg így az is elképzelhetö, hogy bár egy település népessége csökken, mégis mint népességkoncentráló gócpont kerül számításba, ha a népességcsökkenése az országos átlagnál kisebb. Másrészt a szuburbanizáció egy olyan időszakban indult meg, amikor a gazdaságban jelentős visszaesés volt megfigyelhetö, a népesség széles rétegeinek megélhetési viszonyai romlottak, a lakásépítés dinamizmusa is alacsony szintre csökkent. Harmadrészt a szuburbanizáció sokkal jelentősebb falusi szektor mellett (mindössze 55-65\% a városi népesség aránya) indult meg, mint az urbanizáció hasonló szakaszában nyugaton. Ráadásul a városi népesség egy része olyan településeken él, amelyek csak jogilag városok, tényleges városi funkciókkal 
nem vagy csak alig rendelkeznek. Így a ,potenciális kikölttözök” köre szükebb, mint a nyugati országokban, valószínúleg csökkentve ezzel a szuburbanizáció mértékét.

Mindezekkel együtt a kilencvenes években Magyarországon mintegy harmincharmincöt olyan város volt, ahol megfigyelhetö a szuburbanizáció jelensége, amelyek körül dinamizálódott, népességüket növelö falvak találhatóak.

\section{A szuburbanizáció Pécs környékén}

Az 1990-es évek éles törést jelentettek Baranya megye településeinek demográfiai folyamataiban. Pusztán a népességszámok változását vizsgálva, a növekvő népességủ települések száma a negyvenes évek óta folyamatosan csökkent (1. táblázat). Az 1980-as évekre már a megye településeinek kevesebb, mint 10\%-a mutatott népességnövekedést, úgy, hogy a növekvö lakosságú városok száma is jelentösen lecsökkent. Ehhez képest állt be jelentős fordulat a kilencvenes évek közepére, igaz továbbra is többségben vannak a csökkenö lélekszámú falvak, viszont egyrészt a növekvő lakosságú városok száma kettőre csökkent (Bóly, Szentlörinc), és ami még fontosabb, a falvak 38\%-ának (109-nek) újra növekszik a népessége. Természetesen ez a tény önmagában nem igazolja a szuburbanizáció létét Baranya megyében, illetve Pécs körül, de mindenképpen jelzi a változásokat. Külön kiemeltük a vizsgálatunk során azokat a Baranya megyei településeket, amelyek közúton Pécstöl nincsenek messzebb $25 \mathrm{~km}$-nél. Összesen 72 ilyen hely volt, közöttük három város (Komló, Pécsvárad, Szentlőrinc), a többi község. A vizsgált területhez hozzávettünk magát Pécs városát is, valamint a területi folytonosság megörzése végett a közlekedési helyzete miatt az eddig enklávéként jelentkező Aranyosgadányt, s így végül 74 település képezte a vizsgálat ezen részének tárgyát.

\section{TÁBLÁZAT}

A növekvö népességü települések százalékos aránya Baranya megyében.

(The Share of Settlements with Increasing Population in Baranya County)

\begin{tabular}{lcccccc}
\hline & $1941-1949$ & $1949-1960$ & $1960-1970$ & $1970-1980$ & $1980-1990$ & $1995-1998$ \\
\hline Baranya & 53,8 & 29,3 & 19,2 & 14,5 & 9,8 & 36,8 \\
megye & 90,0 & 90,0 & 100,0 & 100,0 & 40,0 & 20,0 \\
Város & 52,6 & 27,2 & 16,4 & 11,5 & 8,7 & 37,3 \\
Község & &
\end{tabular}

Megjegyzés: A városok adatai mindig a jelenlegi tíz városra értendỏek.

1990-ig az 1990-es, 1995-1998 között az 1998-as településállomány figyelembe vételével, Dunafalvával.

Forrás: KSH alapján saját számítás.

Ugyancsak a népességszám változását vizsgálva a növekvỏ lakosságszámú települések mennyisége e szükített területen is folyamatosan csökkent az 1940-es évek óta, úgy, hogy minden évtizedben szám szerint is többen voltak a csökkenö lélekszámú települések. Az 1980-as évekre már csak 12 település növelte a népességét a 74-böl, köztük két város (Pécs, Szentlörinc), majd a kilencvenes évek közepére hirtelen 42 növekvő lakosságszámú települést találunk, s köztük a vizsgált térség 
Bajmócy Péter : A „vidéki" szuburbanizáció Magyarországon, Pécs példáján.

Tér és Társadalom 14. évf. 2000/2-3. 323-330. p.

négy városa közül csak egyet (Szentlörinc), s ez azt jelenti, hogy a Pécshez legközelebb lévő 73 település $58 \%$-ának nö a népessége a kilencvenes évek közepén. A kilencvenes évekhez hasonló vagy ennél magasabb növekedési arányt csak két évtizedben, az 1880-asban és az 1920-asban jegyeztek fel eddig, azaz a jelenlegi évtized folyamatai mindenképpen markánsnak tekinthetök Pécs környékén (is), különösen, ha hozzátesszük, hogy jelenleg a természetes fogyás korábban békeidöben soha sem tapasztalt mértéket ölt nemcsak országosan, hanem speciálisan Baranyában is (1997-ben a természetes fogyás a megyében 4,1 ezrelék volt).

A szuburbanizáció mérésére legalkalmasabb adatoknak a népességváltozás mértéke (és/vagy a vándorlási különbözet) valamint a lakásépítés dinamizmusa tủnnek. A Pécs környéki települések lakónépességének változása azonban korántsem mutat olyan szabályos képet, mint amit a prekoncepciónk alapjản várni lehetne, a klasszikus centrum-periféria növekedés már a múlté. A megye perifériális térségeiben legalább annyi növekvő népességü település található, mint a megyeszékhely közelében. Sö́t a legnagyobb arányú népességnövekedést nem is „szuburbán jellegü” települések, hanem különbözỏ aprófalvak (Adorjás, Babarcszőlös) érik el, és csak utánuk következnek a pécsi agglomeráció legdinamikusabban növekedö, relatíve kis népességü községei (Cserkút, Gyód, Pogány, Keszü). Azonban míg Pécs környékén az előzőekben lehatảrolt 74 település közül 43 (58\%) mutatott népességnövekedést, és csak 11 (15\%) került a legkedvezőtlenebb kategóriába, addig a teljes megye esetében $37 \%$ növekszik és $31 \%$ népessége fogy gyorsan. A kép tehát, ha nem is tünik kristálytisztának, azért mindenképpen jelentös a Pécs környéki települések előnye. Még inkább megmutatkozik ez, ha nem arányaiban, hanem abszolút értékben vizsgáljuk a népességnövekedést. Ekkor az öt legjobban növô település már mind Pécs környéki (1995-97 között, három év alatt Kozármisleny népessége 200 , Pogány 105 , Szentlörinc 103 , Nagykozár 88 , Szederkény 80 fövel növekedett, s a 15 leggyorsabban növekedö település közül is 13 Pécs környéki. (Kivétel az igen magas természetes szaporodással rendelkezö cigányság által lakott Alsószentmáron, valamint a megyei szinten nagy népességủ Mágocs.) A kilencvenes évek közepén Baranyában Pécs szenvedi el messze a legnagyobb fogyást (évi 1200-1300 fó).

A népességváltozást azonban nemcsak a vándorlások, hanem a természetes fogyás is befolyásolja, s mivel e mutató tekintetében is igen nagyok a különbségek a megyén belül, érdemes most külön csak a văndorlásokat megfigyelni. Ha a legnagyobb vándorlási nyereséggel rendelkező településeket vesszük szemügyre az arányokat tekintve ismét vegyes a kép, az abszolút értékeknél pedig szintén hasonló a helyzet a népességnövekedéshez, mindössze hiányoznak a magas természetes szaporodással rendelkezö falvak, illetve megjelennek - szintén nem szuburbán típusként - azok a községek, amelyekben egy nagyobb szociális otthon torzítja a vándorlási adatokat (Somberek, Görcsöny, Vásárosdombó és részben Szederkény is). 
Bajmócy Péter : A „vidéki" szuburbanizáció Magyarországon, Pécs példáján.

Tér és Társadalom 14. évf. 2000/2-3. 323-330. p.

A ,vidéki" szuburbanizáció...

\section{Területi különbségek a szuburbanizáció mértékében}

Pécs környékén tehát megindult a szuburbanizációs folyamat, azonban ez korántsem egyenletes mértékben érinti az egyes Pécs környéki településeket. Az, hogy pontosan hány dinamizált település található a megyeszékhely körül, a vizsgálat jelenlegi állapotában pontosan nem határozható meg, azonban ténylegesen is nehéz lehet eldönteni, hogy mikortól nevezhető egy folyamat szuburbanizációnak, mikortól nevezhetünk egy községet a népességszám-változás szempontjából dinamikusnak.

Pécs környékén a dinamizált települések egy kb. 20-25km-es zónában veszik körül a várost. Ez persze nem azt jelenti, hogy ezen a körön belül minden település „szuburbán” jellegü, hanem inkább azt, hogy ezen a körön kívül nem érdemes jelenleg keresgélni. Pécs esetében is igaz az, hogy a város közigazgatási területén ma már nem állnak bőven rendelkezésre szabad, jó fekvésü területek. A szabad földterület egy részét a Mecsek foglalja el, ugyan ez a terület magas presztízsü, de a jelenleg beépíthető terület korlátozott, illetve vannak szabad területek a város déli, a Pécsi-víz menti területein, részben alacsony presztízzsel. Így aki új kertes, családi házra vágyik, annak sokkal inkább a város közelében lévő falvakban nyílik lehetösége ennek realizálására.

A Pécs körüli dinamikus zónában lévő falvak fejlődése azonban igen jelentős különbségeket mutat. A differenciák legföbb magyarázó tényezőjének a várostól való távolság bizonyult. A leggyorsabb növekedést a Pécshez legközelebbi falvak mutatnak, és a távolság növekedésével csökken a dinamikus falvak aránya. A távolság jelen esetben nem konkrét légvonalbeli távolságot jelent, hanem sokkal inkább elérhetőséget. Mivel azonban a Pécs körüli, elsősorban a Pécstől délre eső területek úthálózatában felfedezhetök a sugarasság jegyei, így az elérhetőséget jól közelíti a közúton mért távolság. Elönyösebb helyzetben vannak azonban a fớtvonalak mentén elhelyezkedö falvak, itt a szuburbán zóna csápszerúen megnyúlik, mint pl. a Pécs-Mohács út mentén Szederkényig, vagy a Pécs-Szigetvár úton Szentlörincen túlig. Ahol azonban a közúti összeköttetés nem megfelelő, oda a várhatónál sokkal lassabban indul meg a kiköltözés. Ilyen, pl. a csak jelentős kerülővel elérhető Aranyosgadány vagy a Mecsek túlsó, északi oldalán fekvö települések. A kiköltözéseket befolyásolja a falvak mérete is. Minél nagyobb egy falu népessége, annál többen költöznek ki. Ez önmagában is figyelembe veendő tény, amely egyáltalán nem lenne triviális. Magyarázatul az szolgálhat, hogy egyrészt a nagyobb falvak infrastrukturális és szolgáltatási ellátottsága jobb, mint a kisebbeké, így az ilyen jellegú hátrányok nem jelentenek gátló tényezöt a kiköltözési döntések meghozatalában. Másrészt a jelenlegi hazai szuburbanizációs folyamatban igen jelentős az informális hírforrások, áramlási csatornák szerepe, s egy nagyobb falu esetén egyszerủen több az esély, hogy egy rokon, ismerős már ott lakik, aki információt szolgáltathat az adott település elönyeirỏl. 
Bajmócy Péter : A „vidéki" szuburbanizáció Magyarországon, Pécs példáján.

Tér és Társadalom 14. évf. 2000/2-3. 323-330. p.

\section{A szuburbanizáció motivációi}

A szuburbanizáció folyamatát a hozzáférhetö statisztikai adatokon túl egy Pécs környékén végzett kérdőives felmérés segítségével vizsgáltuk, melynek eredményei a következőkben foglalhatóak össze. A kérdöivezés során hat Pécs környéki falu (Gyód, Keszü, Kozármisleny, Kökény, Pogány, Szemely) 60 háztartását térképeztük fel, olyan háztartásokat, akik az utóbbi egy évtizedben költöztek az adott faluba. Közülük 53 család Pécsröl érkezett, így végül ök képezték a vizsgálat alapját. A megkérdezett családok nagyobb része értelmiségi, azonban a szakmunkások aránya is jelentős. A vizsgált háztartásoknál a kiköltözések ellenére az aktív kereső családfök nagyobb része (81\%) továbbra is Pécsre jár dolgozni. A vizsgálat igazolta azt a feltevést, hogy a szuburbanizációban részt vevő családok nagyobb része a nagyváros lakótelepeirỏl érkezik a városkörnyéki falvakba. A válaszadó családok 57\%-a ugyanis a Kertváros lakótelepérool érkezett, további 6\%-uk pedig más lakótelepekről (Uránváros, Szigeti városrész). Emellett jelentősnek bizonyult a Belvárosból való kiköltözés (19\%).

Lényeges kérdés lehet a szuburbanizáció vizsgálatánál, hogy mi motiválja az embereket a város elhagyására, a szuburbiákba való kiköltözésre. Ennek eldöntésére néhány tulajdonság alapján értékelniük kellett a válaszadóknak Pécs, illetve szükebben az előző lakás környékét valamint a jelenlegi lakóhelyet. Az eredményeket a 2. táblázat közli.

\section{TÁBLÁZAT}

A korábbi (pécsi) és a jelenlegi lakás, lakókörnyezet, település megitélése a kiköltözōk véleménye alapján ( $1=n a g y o n$ rossz, ... $5=$ =kiváló)

(Opinions of People Who Went to Live in the Country Regarding the Previous

(in Pécs) and the Present House, Environment and Settlement ( $(=$ Very Bad; $5=$ Excellent $)$

\begin{tabular}{lcccc}
\hline & Pécs & Községek & Kozármisleny & $\begin{array}{c}\text { A községek } \\
\text { Kozármisleny } \\
\text { nélkül }\end{array}$ \\
\hline Természeti környezet & 2,85 & 4,6 & 4,71 & 4,56 \\
A levegö tisztasága & 2,58 & 4,68 & 4,65 & 4,69 \\
Zajártalom & 2,47 & 4,38 & 4,47 & 4,33 \\
Szomszédság & 3,62 & 4,51 & 4,59 & 4,47 \\
Közlekedés & 4,28 & 3,58 & 4,12 & 3,33 \\
A munkahely elérhetősége & 4,54 & 3,76 & 4,38 & 3,45 \\
Élelmiszerbolt elérhetősége & 4,65 & 3,84 & 4,25 & 3,66 \\
Szolgáltatások elérhetősége & 4,51 & 3,23 & 3,76 & 2,97 \\
Infrastrukturális ellátottság & 4,43 & 4,13 & 4,53 & 3,94 \\
Közbiztonság & 3,34 & 4,38 & 4,41 & 4,36 \\
\hline
\end{tabular}

Forrás: Kérdöíves felmérés, 1998. szeptember.

Amíg a természeti adottságok esetében markáns a falvak előnye Péccsel szemben, s ugyanez igaz a közbiztonságra valamint a szomszédságra is, addig az ellátottságot, az alapintézmények (munkahely, élelmiszerbolt, szolgáltatások) elérhetőségét 
jóval gyengébbnek ítélik a falvakban, mint a városokban. A falvak közül Kozármisleny mutatói jelentösen eltérnek a többi községétől. Ez a legnagyobb falu Pécs környékén (3889 lakos), és ez is fekszik a legközelebb a városhoz. A falu méretéböl következően a szolgáltatások sokkal jobbak, mint a többi, zömmel 1000 lakos alatti községben, és ez az elérhetőségi mutatók megitélésében is realizálódik. A falvak ellátottsága a szolgáltatások terén a legkedvezötlenebb, így nem meglepö, hogy e szolgáltatások jelentős részét továbbra is Pécsett veszik igénybe a környezỏ falvak lakosai.

Ưgy tűnik, a nyugati szuburbanizációhoz hasonlóan Pécs környékén is a saját családi ház iránti igény a meghatározó a városból való kiköltözések esetében. Annak ismeretében, hogy a kiköltözők nagyobbik része lakótelepekröl érkezik, ez egyáltalán nem tủnik váratlannak. A megkérdezettek 58\%-a esetében döntö, valamint további $8 \%$-nál jelentős szerepet játszott a költözésben a saját ház iránti igény, amelyet leginkább és legolcsóbban a város körüli szuburbanizálódó településeken lehetett kielégíteni. Ezzel összefüggésben a nagyobb lakásméret szükségessége is fontosnak bizonyult (67\%). A Pécsről kiköltözők 57\%-a külön megjegyezte, hogy fontosnak tartja a gazdálkodás lehetőségét a kiköltözést befolyásoló tényezők között. Emellett megjelentek a már-már klasszikusnak tekinthetö sztereotípiák, amelyek a városi élet ellen, illetve a falusi élet mellett szólnak. A szuburbán álom (Fishman 1987) ủgy tünik, Magyarországon is létezik, bár korántsem jut annyira meghatározó szerephez, mint pl. az Egyesült Államokban. A természetközelség, a csend, a nyugalom, a jó levegő, a falusi élet szépsége mind-mind megjelentek a kiköltözés tényezői között, de ugyanígy az is, hogy „el a városból”.

A szuburbanizáció tervezése, az egyes települések közötti, a potenciális kitelepülőkért folytatott verseny szempontjából egyáltalán nem lényegtelen, hogy milyen tényezők alapján választanak települést a migrálók, hogy milyen forrásból szerzik az információkat a településekröl. Meglepỏ módon a közvetett információforrások dominálnak, ezen belül is az informális, döntően hallomás alapján történő információszerzés. A válaszadók valamivel több, mint fele részben vagy egészben hallomás, elmesélés alapján döntött arról, hogy konkrétan az adott településen kíván letelepedni. Emellett azonban számottevő az írott sajtó, mint médiaforrás is, a válaszadók 30\%-a újságban, alapvetően újsághirdetésben találta meg a számára megfelelö telket. Az ez irányú marketingtevékenység még gyerekcipöben jár, legalábbis Pécs környékén, de a válaszokból kikövetkeztethetően és a polgármesteri interjúk alapján bizonyíthatóan már megjelent. A közvetlen információforrás kevésbé jelentős, bár a válaszolók bő harmadának konkrét elözetes vizuális tapasztalata is volt a településről, ahová költözött. A rekreációs szuburbanizáció következményekén sokan oda költöznek végül ki, ahol korábban kiskertjük, nyaralójuk volt, nemegyszer magát a nyaralót átalakítva lakóházzá. 
Bajmócy Péter : A „vidéki" szuburbanizáció Magyarországon, Pécs példáján.

Tér és Társadalom 14. évf. 2000/2-3. 323-330. p.

\section{Irodalom}

Cséfalvay Z. (1994) A modern társadalomföldrajz kézikönyve. Budapest, Ikva Könyvkiadó KFT. Enyedi Gy. (1976) A Budapest probléma. Földrajz és társadalom. Budapest, Magvetö Kiadó. 294-315 o. Enyedi Gy. (1988) A városnövekedés szakaszai. Budapest, Akadémiai Kiadó.

Fishman, R. (1987) Bourgeois Utopias: The rise and fall of suburbia. New York, Basic Books.

Mészáros R. (1994) A település térbelisége. Szeged, JATE-Press.

Rechnitzer J. (szerk.) (1985) Vonzáskörzetek-Agglomerációk ll. Budapest, Akadémiai Kiadó.

Tímár J. (1995) Az alföldi szuburbanizáció sajátosságai. Kandidátusi értekezés. Békéscsaba.

\section{SUBURBANIZATION IN HUNGARY - A CASE STUDY OF PÉCS}

\section{PÉTER BAJMÓCY}

The suburbanisation - the second stage of the urbanisation process - started in Hungary in the middle of the 1980's. The out migration from the centres of the largest towns to the ring and to the villages around them started at this time, first in Budapest, then in about 1990 in the other larger towns. This article examines the scale and the reasons of this process around Pécs, the fifth largest Hungarian town. In the 1990's all the settlements near Pécs had population growth. At that time the population of Baranya county decreased. Most of the people who migrated out from Pécs were intellectual workers, who came from one of the large block of flats of Pécs. They appreciate the villages better than Pécs due to the environment, neighbourhood and the public security, but Pécs still has better accessibility factors. 